\title{
What Drives Successful Complaint Resolutions on Social Media?: Evidence from the Airline Industry
}

\author{
Priyanga Gunarathne \\ University of Rochester \\ priyanga.gunarathne@simon.roc \\ $\underline{\text { hester.edu }}$
}

\author{
Huaxia Rui \\ University of Rochester \\ huaxia.rui@simon.rochester.edu
}

\author{
Avi Seidmann \\ University of Rochester \\ avi.seidmann@simon.rochester. \\ $\underline{\text { edu }}$
}

\begin{abstract}
Several companies effectively manage customer complaints on social media today, interacting with their customers on a real time basis. To study this increasingly popular practice, we examine brands' complaint resolution efforts on social media, by exploiting a unique dataset of complaint-based customer interactions on Twitter, with a major airline. We find that complaining customers with a higher number of followers are more likely to be satisfied about their social media interaction with the brand. Moreover, the customers having an outcome related complaint, rather than a process related complaint, and also the customers who do not experience handoffs during the conversation, are more likely to be satisfied about their complaining experience on social media. To the best of our knowledge, this study is the first to empirically investigate the potential drivers of successful complaint resolutions in the context of social media customer service.
\end{abstract}

Key Words: social media, social surveillance, social influence, complaint management

\section{Introduction}

Empowered by the popularization of social media and mobile technologies, consumers nowadays easily distribute their complaints to brands publicly in real time, expanding the boundaries of traditional customer service. Such a public approach may actually work out for the consumers in the digital age, rather than spending hours on the phone to contact the brand's dedicated customer service. As a result, more and more customers are turning to social media platforms such as Twitter and Facebook to express their complaints to brands on social media. In response, companies are striving to monitor and respond to their customers, before complaints go viral and cause reputational damage for the organization.
Regardless of how excellent the service may be a company delivers, every company often makes mistakes in meeting the expectations of customers [1]. Previous studies indicate that failures themselves do not necessarily lead to customer dissatisfaction, since most customers accept that things may sometimes go wrong [2]. Instead, the service provider's response or lack of response to the failure is the most likely cause of dissatisfaction [3]. Traditionally, customers entered into the organizational complaint management process by directly contacting the dedicated customer service of the brand, and the communication with the customer was always kept private and confidential. In contrast, social media has enabled customers to publicly report their concerns online to the respective brand, and brand's dedicated social media team enters into conversation with the customer openly. The social media team sits between the customer and the dedicated customer service of the brand, and the conversation may be open to third-party audiences such as followers of the customer, or practically to anybody if the posts do not assume any privacy. Even though the social media teams may not be as empowered as the dedicated customer service of the brand, their empathy in interacting with the customer and their commitment in finding solutions might make a difference in the mind of the customer, and could convert an angry or unhappy customer into a calm, relieved or even happy customer at the end of the interaction.

Inspired by this growing phenomenon, in this study, we examine three potential drivers of satisfaction of a customer complaining to a brand on social media. First, we examine whether a customer's social media influence affects his chance of feeling better about a social media interaction with a brand regarding a complaint, as opposed to feeling worse, or the same. Second, we investigate whether complaining customers are more likely to feel better about their social media interaction with a brand regarding an outcome (i.e. operations) related complaint, than a process (i.e. employees) related complaint. Third, we examine whether the customers complaining to a brand on social 
media are more likely to feel worse about their social media interaction, if handoffs occurred during the conversation.

To address our research questions, we analyzed a unique dataset of complaint based conversations exchanged between customers and a major airline on Twitter. In order to learn customers' perception of how they felt at the end of the social media interaction with the airline, we conduct our Closed Loop Social Surveillance (CLSS) survey methodology among a random sample of 1,500 customers who engaged in a complaint-based conversation with the airline on Twitter.

Our paper makes important contributions to the field of information systems research and service management, in the social media era. Previous studies mostly looked at the causes and the sources of the customers' complaints and the procedural determinants of the organizational complaint management process, with specific focus on repurchase intentions, potential word of mouth and customer satisfaction with the resolution outcomes. To the best of our knowledge, this study is the first to empirically investigate the potential drivers of complaining customers' satisfaction, in the context of social media customer service. Another important contribution of this research is the Closed Loop Social Surveillance methodology that we created to survey ex-post customers served on social media. Although several studies have used social media data to make important research inferences, we leverage the power of social surveillance to establish the missing link between researchers and actual customers on social media in extending or validating the research outcomes.

The rest of the paper is organized as follows. We first review relevant literature and then develop the hypotheses for our research questions. Then we describe our data, measures, and methodology, and then estimate the models and present the results. We conclude the paper by discussing the implications for policy and practice.

\section{Literature Review}

The value of complaints both as a communication device and as a means of giving the firm a chance to turn a dissatisfied customer into a satisfied and loyal one has long been recognized by researchers [4]. In fact, complaint management refers to the strategies used by the brands to resolve disputes and to improve ineffective products or services in order to establish a firm's reliability in the eyes of the customers [5].

Tax et. al. [5] examined customer evaluations of service complaint experiences and find that a majority of complaining customers were dissatisfied with recent complaint handling experiences. Using justice theory, they demonstrate that customers evaluate complaint incidents in terms of the outcomes they receive, the procedures used to arrive at the outcomes, and the nature of the interpersonal treatment during the process. Levesque et. al. [6] investigated the connection between the type of problems and customer dissatisfaction responses to issues associated with service outcomes, service process, pricing and location. Their findings suggest that customers are more likely to voice than to exit when they encounter problems and the importance of the problem is linked to the rate of taking action.

Estelami [7] examined the impact of various procedural determinants of complaint handling such as compensation, employee behavior and promptness, on the creation of outstanding complaint resolutions. They find that consumer delight and disappointment with complaint outcomes are primarily influenced by compensatory aspects of complaint resolutions. Davidow [8] examined how customers assess the organizational responses to complaints, and impact of those assessments on future consumer behavior. They find attentiveness as the most important organizational response dimension, affecting both word-of-mouth activity and repurchase intentions. Strauss and Hill [9] explored company responses to genuine complaints via email and consumer reactions to those responses. They found $47 \%$ of the firms responded to the complaint emails which in turn resulted in higher customer satisfaction and purchase likelihood. Additionally, response e-mails that were received quickly, addressed the specific problem and signed with an employee's name resulted in higher customer satisfaction.

The importance of emotion is gaining attention as a central element in understanding the consumption experience of customers [10]. Service failure and recovery encounters may be pivotal moments for customers, many of whom experience strong emotional reactions in response to service failures and subsequently decide whether to continue their relationship with the organization [11]. Prior research [12][13] find that customers are more emotionally involved in, and more observant of, recovery service than routine or first-time service.

All these studies have provided important insights into the customer complaint management procedures in organizations, in a variety of contexts. However, there is surprisingly limited understanding of complaining customers' satisfaction over complaint resolution efforts taken place on social media. We fill this gap and contribute to the stream of research literature on customer complaint management in the digital age. 


\section{Hypotheses}

The concepts of service level differentiation and prioritized customer service existed from the early days of service provision and shared resources, with evidence dating back to the dawn of civilizations [14]. The idea of preferential treatment is not new to customers nowadays as several firms are redefining the service levels to treat their best customers better. For example, frequent flier programs in airlines offer priority boarding and first class/business class upgrades to their frequent travelers. With the convergence of social media and customer service, it is not only the values that customers bring in that matters to a company, but also the ability of those customers to influence others in the social network [14]. By targeting influential individuals in a network, a chain reaction of influence driven by word of mouth can be activated such that a large portion of the network can be reached with a small marketing cost [15]. For example, on Twitter, a single tweet posted by someone with a few thousand followers can reach thousands of people almost instantly, and reach even more people when those followers retweet the original tweet.

Nowadays, several firms seem to make use of customers' social network information to refine their customer service strategies. For example, for limited periods in recent years, American Airlines and Cathay Pacific Airways granted high Klout scorers the access to their exclusive airport lounges, which would have been otherwise available only to their first class or business class passengers. Recently, Genesys, a global omnichannel customer experience and contact center solution provider for business clients including major airlines, banks and telecommunications companies, integrated Klout score into its solutions. This enabled companies that use the Genesys platform to recognize their customers with high Klout scores and route them to specialized customer service agents, if they wish to do so.

This differential treatment may be driven by a company policy of service level differentiation that strategically allocates more resources to handle possibly influential customers, in order to minimize the risk of a social media crisis. Or else, even without an explicit company policy, the social media team may be facing an internal incentive mechanism that punishes negligence that leads to complaints from high risk customers going viral on social media. Even in the absence of such explicit company policy or an implicit incentive mechanism, driven by the human nature and by the abundance of information on social media, the social media team may generate highly positive perceptions of socially popular customers and thus serve them better than others. Although to which extent this practice is present in social media customer service is yet unknown, highly influential, hence also high-risk customers may be treated better on social media, so they are more likely to feel better about their overall complaining experience, than the less-influential ones.

In contrast, the less-influential customers could be unhappy about their overall complaining experience on social media for two reasons. First is the undertreatment itself, received from the brand regarding the complaint. Second is the perceived unfairness that they witness, seeing the brands' interactions with other customers on social media. Service fairness is a customer's perception of the degree of justice in a service firm's behavior [31]. The concept of justice has evolved over time to include distributive justice (dealing with decision outcomes), procedural justice (dealing with decision-making procedures) and interactional justice (dealing with interpersonal behavior in the enactment of procedures and delivery of outcomes) [5]. In the context of preferential treatment in customer service, the distributive justice is particularly violated because the nature of differential customer treatment is about the unfair distribution of a social media team's attention and time among customers. Therefore, we argue that the practice of social media influence based preferential customer treatment will be perceived as unfair by customers, especially the less influential, hence rather disadvantaged customers on social media. Previous research indicates that the perceived service unfairness influences customers' negative emotional reactions, such as feelings of betrayal and anger, as well as their behavioral responses, such as venting and revenge. On social media, these reactions may lead to dissatisfaction regarding the complaining experience that could lead to immediate discontinuation of patronage, while the negative word of mouth across the social network can prove detrimental to the company in the long term. Based on these arguments, we propose the following hypothesis for empirical test.

Based on these arguments, we propose the following hypothesis for empirical test.

H1: A complaining customer with a higher number of followers is more likely to feel better, than to feel the same or worse at the end of a conversation with a brand on social media.

Next, we look at the social media customer service related aspects that might affect customer's emotional status at the end of the encounter with the brand.

Consumer complaints are getting increasingly complex in the digital age. For example on social media, airline passengers complain about flight delays, cancellations, missed flights, long queues at airports, mishandled baggage, computer system failures, in-flight issues and unprofessional airline employees, in real time and in public. Studies that empirically investigate the 
connection between the type of complaint and the complaint handling outcomes are rare in the literature. When customers deal with service firms, the two main reasons for customer complaints are the failure to deliver the service and how the service was delivered [16]. These two problems are commonly referred to as outcome (contractual aspects of the service) and process (customer-employee relationship aspects of the service) related problems in the literature [6][24][25]. Outcome involves the performance aspects of the service, the ability of the organization to keep the promises and to solve problems when they arise [26]. It is the reliability of the service, and reflects aspects such as accuracy and timeliness [6]. Process involves the functional or people aspects of the service and is a consequence of the behavior and customer oriented service mindedness of the employees [26]. It reflects the tone of the relationship and incorporates empathy and assurance.

According to social exchange and equity theories [32][33], a complaint encounter can be viewed as an exchange in which the customer experiences a loss due to the failure and the organization attempts to provide a gain, in the form of effective complaint handling, to make up for the customer's loss. Service failures can result in the loss of economic (money, time) or psychological/social (status, empathy, esteem) resources for customers, making organizations to recover by offering customers economic resources in the form of compensation, or psychological/social resources such as an apology [3]. An outcome failure involves a loss of economic resources, whereas a process failure involves a loss of psychological/social resources. Thus, we expect customers' complaint satisfaction judgments to differ by the type of complaint, as outcome and process failures represent different categories of loss to the customer. Marketing literature provides very limited evidence on which type of failure has more influence on customers' complaint satisfaction judgments. Smith et. al. [3] find that the customers who experienced process failures were more dissatisfied than those who experienced outcome failures. Bitner et. al. [16] found that a large percentage of unsatisfactory service encounters were related to employees' inability or unwillingness to respond effectively to service failure situations. Furthermore, prior studies indicate that operational failures themselves do not necessarily lead to customer dissatisfaction, since most customers accept that things may sometimes go wrong [2]. However, if it is the organizational employees which failed to live up to customer expectations of service, it is less likely that they will be satisfied with their experience. Based on these arguments, we propose the following hypothesis for empirical test.
H2: A complaining customer is more likely to feel better, than to feel the same or worse at the end of a conversation with a brand on social media, if the complaint is outcome related than process related.

When a service failure occurs, customers often contact employees to seek compensation or explanations. The manner in which these employees interact with the complaining customer could have a significant impact on the customer's emotional status at the end of the encounter. When a customer voices a complaint to a brand, it is usually expected that the problem will be resolved at the first point of contact.

Empowerment is the authority to act and refers to the resources to which employees have access and the decisions they are permitted to make [34]. When a customer voices a complaint to a brand, it is usually expected that the problem will be resolved at the first point of contact. Often, frontline employees are not expected to use their discretion or to participate actively in unusual or unexpected situations which customer complaints inevitably are [34]. In other words, frontline employees are often not sufficiently empowered to respond actively to customer complaints. It might not matter how friendly, pleasant, or attentive an employee is to a customer if the employee is not able to solve the problem or to be seen as trying to help, as the customer will just become more dissatisfied [35]. Prior studies find that full empowerment to solve the complaint immediately has a significant impact on satisfaction with the recovery [36]. However, it is questionable whether the brands providing customer service on social media today have the ability and authority to fully rectify customer complaints. In case the social media team is not empowered enough to resolve complaints fully, as compared to the brand's dedicated customer care service, handoffs may be inevitable, causing dissatisfaction for the complaining customers. Based on these arguments, we propose the following hypothesis for empirical test.

H3: A complaining customer is more likely to feel worse, than to feel the same or better at the end of a conversation with a brand on social media, if a handoff occurred during the conversation.

\section{Data, Measures, and Methodology}

Our data is constructed from complaint based conversations on Twitter between customers and an airline that we would like to keep anonymous. We define a conversation as a dialogue between a customer and an airline on Twitter, containing all the tweets the customer sent to the airline on a particular complaint, 
plus all the reply tweets received for those tweets from the airline. In order to visualize the Twitter conversations between the airline and customers, we developed a program that displays all the conversations each customer had with the airline in a particular duration. Then, for further analysis, we randomly picked 1,500 complaint based conversations initiated by different customers. Taking the concise nature of communication on Twitter into account, we only picked the conversations with at least two replies from the airline. In order to learn how these customers felt at the end of the conversation they had with the airline on Twitter, we applied our Closed Loop Social Surveillance (CLSS) survey methodology.

\subsection{The Closed Loop Social Surveillance (CLSS) Survey Methodology}

Although conducting surveys has long been a reliable method of learning customer perceptions, collecting such data from brands may not always be possible for the researchers due to the difficulty in communicating directly with the customers. Nevertheless, consumers are becoming pivotal authors of brand stories due to new dynamic networks of consumers and brands formed through social media and the easy sharing of brand experiences in such networks [17]. As a result, social surveillance, or in other words, the use of social media sites like Twitter and Facebook to see what friends, family, and acquaintances are up to [18][19][20], has enabled researchers to continually investigate digital traces left by people they are connected to through social media [19]. We extend this increasingly popular phenomenon of using social media data for research and propose the Closed Loop Social Surveillance (CLSS) survey methodology, which enables us to learn customer perceptions on brands' service interventions on Twitter. Next, we describe the operationalization of CLSS survey for the present study.

Using the official Twitter account of our university research group, we started following each customer first, as the instantaneous Twitter notification this creates is likely to capture the customer's immediate attention. Next, we immediately sent out a tweet to the customer asking to follow us back, so we could communicate via direct messages (DM), keeping the conversation private and confidential. This tweet took the following form: "Hi Amy, we are studying how airlines treat customers on Twitter. Could you follow us so we can DM you 2 short questions? Thanks!" If the customer followed us back indicating the preference to interact, we sent a couple of direct messages asking two short questions: "Thx Amy. We are collecting voices on @ airline to monitor their service. We want to learn your Twitter experience with them on December $7^{\text {th" }}$ and then “(Q1) Did@airline solve your problem? (Q2) Did your conversationwith @airline make you feel better,worse, or the same?" Upon receiving responses from the customer, we ended the conversation with a thank-you note.

As expected, not all the customers we followed, followed us back. Some customers followed us, but did not respond to our DMs. Some customers who responded to our DMs did not stop at providing the answers, but explained their actual experience with the airline in detail. We offered the survey to 1,500 different customers and heard back from 503 customers, which is a response rate of $33.54 \%$.

\subsection{Variables}

Dependent Variable: Our empirical strategy uses the dependent variable Emotional Outcome, which equals to 1 if the customer felt better, -1 if the customer felt worse, and 0 if the customer felt the same, at the end of the conversation with the airline.

Independent Variables: The primary independent variables of interest are the number of followers each customer had at the start of the conversation, the complaint type (i.e. whether the complaint is outcome or process related), and whether a hand-off occurred during the conversation (i.e. whether the social media team handed-off the customer to some other department to be taken care of). Table 1 explains the key variables in our empirical analysis.

Surprisingly, $53.2 \%$ of the customers reported that they felt worse at the end of the conversation with the airline on Twitter, while only $19.8 \%$ of the customers felt better and $27 \%$ felt the same. Among various types of complaints present in the conversations, flight delays, cancellations, mishandled baggage, in-flight service, and other operations related issues contributed to about $65 \%$ of the total complaints. The rest of the complaints were process related, including the complaints related to unprofessional employees or the airline's dedicated customer service. Furthermore, only $10.6 \%$ of the customers believed that the airline's social media team resolved their problem. This was more evident among the customers who felt worse at the end, as $94.36 \%$ of them did not perceive their problem been resolved. Moreover, 39\% of the customers reported hand-offs, instead of having their complaint rectified by the social media team.

\section{Analysis}

We assume that the perceived satisfaction from complaining to an airline on social media for customer $i$ in conversation $j$ is $\mathrm{Y}_{\mathrm{ij}}^{*}$, where

$$
\mathrm{Y}_{\mathrm{ij}}^{*}=\beta_{0}+D_{j} \beta_{1}+C_{i j} \beta_{2}+\varepsilon_{i j}
$$


Here, $D_{j}$ refers to the vector of observable characteristics of conversation $j$, and $C_{i j}$ refers to the vector of observable characteristics of customer $i$ in conversation $j . \varepsilon$ is the error term with cumulative distribution function $G$ such that $G(x)=1-G(-x)$.

Let $Y_{i j}$ be an ordered outcome of whether the customer felt worse, the same, or better at the end of the conversation with the brand, taking on the values $\{-1,0$, $+1\}$ respectively. Let $\tau_{1}<\tau_{2}$ be unknown thresholds such that

$$
\begin{array}{rll}
Y_{i j}=-1 & \text { if } & Y_{i j}^{*} \leq \tau_{1} \\
Y_{i j}=0 & \text { if } & \tau_{1}<Y_{i j}^{*} \leq \tau_{2} \\
Y_{i j}=+1 & \text { if } & Y_{i j}^{*}>\tau_{2}
\end{array}
$$

For simplicity, we denote the conversation and customer-related variables and the constant term as $X_{i j}$. The conditional distribution of $Y_{i j}$ given $X_{i j}$ can be defined as:

$\operatorname{Pr}\left(\mathrm{Y}_{\mathrm{ij}}=-1 \mid \mathrm{X}_{\mathrm{ij}}\right)=\operatorname{Pr}\left(\mathrm{Y}_{\mathrm{ij}}^{*} \leq \tau_{1} \mid \mathrm{X}_{\mathrm{ij}}\right)=\mathrm{G}\left(\tau_{1}-\mathrm{X}_{\mathrm{ij}} \beta\right)$

$\operatorname{Pr}\left(\mathrm{Y}_{\mathrm{ij}}=0 \mid \mathrm{X}_{\mathrm{ij}}\right)=\operatorname{Pr}\left(\tau_{1}<\mathrm{Y}_{\mathrm{ij}}^{*} \leq \tau_{2} \mid \mathrm{X}_{\mathrm{ij}}\right)$

$=G\left(\tau_{2}-X_{i j} \beta\right)-G\left(\tau_{1}-X_{i j} \beta\right)$

$\operatorname{Pr}\left(Y_{i j}=1 \mid X_{i j}\right)=\operatorname{Pr}\left(Y_{i j}^{*}>\tau_{2} \mid X_{i j}\right)=1-G\left(\tau_{2}-X_{i j} \beta\right)$

The log likelihood function is given by

$\mathrm{L}_{\mathrm{i}}(\tau, \beta)=$

$1\left[\mathrm{Y}_{\mathrm{ij}}=-1\right] \log \left[\mathrm{G}\left(\tau_{1}-\mathrm{X}_{\mathrm{ij}} \beta\right)\right]+1\left[\mathrm{Y}_{\mathrm{ij}}=0\right] \log \left[\mathrm{G}\left(\tau_{2}-\right.\right.$

$\left.\left.X_{i j} \beta\right)-G\left(\tau_{1}-X_{i j} \beta\right)\right]+1\left[Y_{i j}=1\right] \log \left[1-G\left(\tau_{2}-X_{i j} \beta\right)\right]$

Assuming that the error term $\varepsilon$ follows a logistic distribution, we estimate an ordered-logit model, to test our hypotheses. The proportional odds assumption has been tested using the likelihood ratio test and Brant's Wald Test. Both tests generated non-significant test statistics confirming no violation of the proportional odds assumption for the suggested model. The regression results are reported in column (1) and column (2) of Table 2.

From Table 2, Log of Followers is positive and statistically significant $(\mathrm{p}<0.01)$. In terms of magnitude, for a one-unit increase in Log of Followers, the odds of feeling better increase by a factor of $1.28(28 \%)$ more than the combined odds of feeling the same or feeling worse. Our findings suggest that as the number of followers increases, there is a corresponding increase in the probability of the customer feeling better at the end of a conversation with the airline on social media, thereby providing support for $\mathrm{H} 1$.

To better evaluate how the probabilities of each emotional outcome changes as Complaint Type and Hand-off vary, we generate the respective predicted probabilities while keeping the rest of the variables at

\begin{tabular}{|c|c|}
\hline Variable & Description \\
\hline $\begin{array}{l}\text { Emotional } \\
\text { Outcome }\end{array}$ & $\begin{array}{l}\text { Customer's emotional status at the end } \\
\text { of the conversation (obtained from Q1 } \\
\text { of the survey) } \\
(-1=\text { worse, } 0=\text { same, } 1=\text { better })\end{array}$ \\
\hline Followers & $\begin{array}{l}\text { Number of followers for the customer } \\
\text { at the start of the conversation }\end{array}$ \\
\hline $\begin{array}{l}\text { Complaint } \\
\text { Type }\end{array}$ & $\begin{array}{l}\text { Binary variable indicating the } \\
\text { complaint type ( } 1=\text { outcome/operations } \\
\text { related, } \\
\text { e.g. flight delay/cancellation, } \\
\text { mishandled baggage, in-flight service, } \\
\text { non-employee related issues at airports } \\
\text { etc.) } \\
0=\text { process/employees/dedicated } \\
\text { customer service related } \\
\text { e.g. rude flight attendants, longer than } \\
\text { usual holding times in contacting the } \\
\text { customer service, response delays from } \\
\text { customer service etc.) }\end{array}$ \\
\hline Hand-off & $\begin{array}{l}\text { Binary variable indicating whether the } \\
\text { social media team handed off the } \\
\text { customer to some other department to } \\
\text { be taken care of }\end{array}$ \\
\hline $\begin{array}{l}\text { Problem } \\
\text { Solved }\end{array}$ & $\begin{array}{l}\text { Binary variable indicating whether the } \\
\text { airline resolved the complaint on social } \\
\text { media }\end{array}$ \\
\hline Apology & $\begin{array}{l}\text { Binary variable indicating whether the } \\
\text { airline apologized }\end{array}$ \\
\hline Explanation & $\begin{array}{l}\text { Binary variable indicating whether the } \\
\text { airline provided an explanation }\end{array}$ \\
\hline $\begin{array}{l}\text { Customer at } \\
\text { the end }\end{array}$ & $\begin{array}{l}\text { Binary variable indicating whether it } \\
\text { was the customer who ended the } \\
\text { conversation }\end{array}$ \\
\hline $\begin{array}{l}\text { Brand Switch } \\
\text { Warning }\end{array}$ & $\begin{array}{l}\text { Binary variable indicating whether the } \\
\text { customer warned the airline about } \\
\text { possible brand switching in future }\end{array}$ \\
\hline $\mathrm{DM}$ & $\begin{array}{l}\text { Binary variable indicating whether the } \\
\text { customer or the airline mentioned about } \\
\text { direct messaging }\end{array}$ \\
\hline $\begin{array}{l}\text { Total Tweets } \\
\text { Exchanged }\end{array}$ & $\begin{array}{l}\text { Total number of tweets exchanged } \\
\text { during the conversation }\end{array}$ \\
\hline $\begin{array}{l}\text { Average } \\
\text { Airline } \\
\text { Response } \\
\text { Time }\end{array}$ & $\begin{array}{l}\text { Average of response times between } \\
\text { airline tweets and their respective } \\
\text { parent user tweets, in seconds }\end{array}$ \\
\hline $\begin{array}{l}\text { Consecutive } \\
\text { User Tweets }\end{array}$ & $\begin{array}{l}\text { Binary variable indicating whether } \\
\text { consecutive user tweets exist in the } \\
\text { conversation }\end{array}$ \\
\hline $\begin{array}{l}\text { Consecutive } \\
\text { Airline Tweets }\end{array}$ & $\begin{array}{l}\text { Binary variable indicating whether } \\
\text { consecutive airline tweets exist in the } \\
\text { conversation }\end{array}$ \\
\hline $\begin{array}{l}\text { Customer } \\
\text { Account Age }\end{array}$ & $\begin{array}{l}\text { Number of days since the creation of } \\
\text { the customer's Twitter account }\end{array}$ \\
\hline $\begin{array}{l}\text { Public Web } \\
\text { Site/Location/ } \\
\text { Profile Bio } \\
\end{array}$ & $\begin{array}{l}\text { Binary variable indicating whether the } \\
\text { user's location, website or profile } \\
\text { description is publicly available }\end{array}$ \\
\hline
\end{tabular}
their means. The results are reported in Table 3 .
Table 1. Definitions of Variables 
Table 2. Ordered Logistic Regression of Customer Emotional Outcome

\begin{tabular}{|c|c|c|c|c|}
\hline \multirow[b]{2}{*}{ Variable } & \multicolumn{2}{|c|}{ Benchmark Model } & \multicolumn{2}{|c|}{ Robustness Test } \\
\hline & $\begin{array}{c}\text { (1) } \\
\text { Ordered Logit } \\
\text { Coefficient }\end{array}$ & $\begin{array}{c}\text { (2) } \\
\text { Ordered Logit Odds } \\
\text { Ratio }\end{array}$ & $\begin{array}{c}(3) \\
\text { Ordered Logit } \\
\text { Coefficient with } \\
\text { LIWC 2001 }\end{array}$ & $\begin{array}{c}\text { (4) } \\
\text { Ordered Logit } \\
\text { Coefficient with } \\
\text { LIWC 2015 }\end{array}$ \\
\hline \multirow{2}{*}{ Log of Followers } & $0.2433 * * *$ & $1.2754 * * *$ & $0.2525 * * *$ & $0.2562 * * *$ \\
\hline & $(0.0629)$ & $(0.0802)$ & $(0.0679)$ & $(0.0682)$ \\
\hline \multirow{2}{*}{ Complaint Type } & $0.6383 * * *$ & $1.8933 * * *$ & $0.5947 * * *$ & $0.5902 * * *$ \\
\hline & $(0.2122)$ & $(0.4018)$ & $(0.2256)$ & $(0.2235)$ \\
\hline \multirow{2}{*}{ Hand-off } & $-0.4740 * *$ & $0.6225 * *$ & $-0.4970 * *$ & $-0.5042 * *$ \\
\hline & $(0.1954)$ & $(0.1217)$ & $(0.2076)$ & $(0.2075)$ \\
\hline \multirow{2}{*}{ Problem Solved } & $1.5130 * * *$ & $4.5402 * * *$ & $1.2909 * * *$ & $1.2752 * * *$ \\
\hline & $(0.3046)$ & $(1.3829)$ & $(0.3233)$ & -0.3217 \\
\hline \multirow{2}{*}{ Apology } & 0.2688 & 1.3084 & 0.2335 & 0.2020 \\
\hline & $(0.2154)$ & $(0.2818)$ & $(0.2298)$ & $(0.2300)$ \\
\hline \multirow{2}{*}{ Explanation } & -0.0985 & 0.9062 & -0.0973 & -0.1297 \\
\hline & $(0.2048)$ & $(0.1856)$ & $(0.2159)$ & $(0.2155)$ \\
\hline \multirow{2}{*}{ Customer at the end } & $-0.4517 * *$ & $0.6365 * *$ & $-0.4330 *$ & $-0.4321^{*}$ \\
\hline & $(0.2213)$ & $(0.1409)$ & $(0.2392)$ & $(0.2391)$ \\
\hline \multirow{2}{*}{ Brand Switch Warning } & $-0.5741 * *$ & $0.5632 * *$ & $-0.7449 * * *$ & $-0.7380 * * *$ \\
\hline & $(0.2273)$ & $(0.1280)$ & $(0.2538)$ & $(0.2527)$ \\
\hline \multirow{2}{*}{ DM } & 0.3019 & 1.3524 & 0.2566 & 0.2695 \\
\hline & $(0.2579)$ & $(0.3488)$ & $(0.2717)$ & $(0.2717)$ \\
\hline \multirow{2}{*}{ Total Tweets Exchanged } & $-0.1031 * *$ & $0.9021 * *$ & $-0.1212 * * *$ & $-0.1196 * * *$ \\
\hline & $(0.0432)$ & $(0.0390)$ & $(0.0462)$ & $(0.0461)$ \\
\hline \multirow{2}{*}{$\begin{array}{l}\text { Log of Average Airline } \\
\text { Response Time }\end{array}$} & -0.0181 & 0.9820 & 0.0098 & 0.0209 \\
\hline & $(0.0964)$ & $(0.0947)$ & $(0.1027)$ & $(0.1024)$ \\
\hline \multirow{2}{*}{ Consecutive User Tweets } & 0.1181 & 1.1254 & 0.2548 & 0.2383 \\
\hline & $(0.2240)$ & $(0.2521)$ & $(0.2428)$ & $(0.2431)$ \\
\hline \multirow{2}{*}{$\begin{array}{l}\text { Consecutive Airline } \\
\text { Tweets }\end{array}$} & 0.7139 & 2.0420 & 0.6277 & 0.6895 \\
\hline & $(0.9838)$ & $(2.0089)$ & $(0.9967)$ & $(0.9909)$ \\
\hline \multirow{2}{*}{ Customer Account Age } & -0.0002 & 0.9998 & -0.0002 & -0.0002 \\
\hline & $(0.0002)$ & $(0.0002)$ & $(0.0002)$ & $(0.0002)$ \\
\hline \multirow{2}{*}{$\begin{array}{l}\text { Public Web } \\
\text { Site/Location/Profile Bio }\end{array}$} & -0.3792 & 0.6844 & $-0.6250 *$ & $-0.6304 *$ \\
\hline & $(0.3085)$ & $(0.2111)$ & $(0.3396)$ & $(0.3385)$ \\
\hline \multirow{2}{*}{ Agreeableness } & - & - & -0.0462 & -0.0036 \\
\hline & - & - & $(0.1388)$ & $(0.1625)$ \\
\hline \multirow{2}{*}{ Conscientiousness } & - & - & $0.6016 * *$ & $0.9390 * *$ \\
\hline & - & - & $(0.2675)$ & $(0.4039)$ \\
\hline \multirow{2}{*}{ Extraversion } & - & - & 0.0620 & 0.2193 \\
\hline & - & - & $(0.1900)$ & $(0.2503)$ \\
\hline \multirow{2}{*}{ Neuroticism } & - & - & 0.1115 & $0.6039 *$ \\
\hline & - & - & $(0.3149)$ & $(0.3588)$ \\
\hline & - & - & -0.0887 & 0.0032 \\
\hline Openness & - & - & $(0.0948)$ & $(0.1177)$ \\
\hline & 0.3335 & 1.3959 & -0.1011 & 0.0130 \\
\hline Cut 1 Constant & $(0.7828)$ & $(1.0927)$ & $(0.9759)$ & $(1.0031)$ \\
\hline & $1.7933 * *$ & $6.0094 * *$ & 1.3476 & 1.4596 \\
\hline Cut 2 Constant & $(0.7880)$ & $(4.7353)$ & $(0.9784)$ & $(1.0060)$ \\
\hline Observations & 500 & 500 & 453 & 453 \\
\hline Log Likelihood & -462.2846 & & & \\
\hline AIC & 958.5692 & & & \\
\hline $\mathrm{BIC}$ & 1030.218 & & & \\
\hline
\end{tabular}


Table 3. Predicted Probabilities

\begin{tabular}{|c|c|c|c|}
\hline Variable & $\begin{array}{c}\text { Emotional } \\
\text { Outcome }\end{array}$ & $\begin{array}{c}\text { Probability } \\
\text { at } 0\end{array}$ & $\begin{array}{c}\text { Probability } \\
\text { at } 1\end{array}$ \\
\hline \multirow{3}{*}{$\begin{array}{l}\text { Complaint } \\
\text { Type }\end{array}$} & Worse & $\begin{array}{r}0.6401 * * * * \\
(0.0418)\end{array}$ & $\begin{array}{r}0.4843 * * * \\
(0.0281)\end{array}$ \\
\hline & Same & $\begin{array}{r}0.2444 * * * \\
(0.0273)\end{array}$ & $\begin{array}{r}0.3174 * * * \\
(0.0237)\end{array}$ \\
\hline & Better & $\begin{array}{r}0.1156 * * * \\
(0.0207) \\
\end{array}$ & $\begin{array}{r}0.1983 * * * \\
(0.0210) \\
\end{array}$ \\
\hline \multirow{3}{*}{ Hand-off } & Worse & $\begin{array}{r}0.4859 * * * \\
(0.0303) \\
\end{array}$ & $\begin{array}{r}0.6029 * * * \\
(0.0371)\end{array}$ \\
\hline & Same & $\begin{array}{r}0.3168 * * * * \\
(0.0241)\end{array}$ & $\begin{array}{r}0.2644 * * * \\
(0.0251)\end{array}$ \\
\hline & Better & $\begin{array}{r}0.1973 * * * * \\
(0.0221)\end{array}$ & $\begin{array}{r}0.1327 * * * \\
(0.0204)\end{array}$ \\
\hline
\end{tabular}

From Table 2, Complaint Type is also positive and statistically significant $(\mathrm{p}<0.01)$. In terms of magnitude, switching from process to outcome related complaint, increases the odds of feeling better by a factor of 1.8933 $(89.33 \%)$ than that of the combined odds of feeling the same or feeling worse. According to the predicted probabilities, there is $64 \%$ chance that the customer feels worse at the end when the complaint is process related, while it is $48.43 \%$ when the complaint is outcome related. Accordingly, our findings suggest that process related complaints are less likely to make a customer feel better at the end of a conversation with an airline on social media, thereby providing support for $\mathrm{H} 2$.

From Table 2, Hand-off is negative and statistically significant $(\mathrm{p}<0.05)$. In terms of magnitude, taking care of the customer by the social media team rather than handing off the customer to some other department, decreases the odds of feeling better by a factor of 0.6225 $(37.75 \%)$ than that of the combined odds of feeling the same or feeling worse. Moreover, the predicted probabilities indicate that there is $60.29 \%$ chance that the customer feels worse when a hand-off occurred, as opposed to the $48.59 \%$ probability of feeling worse when the social media team takes care of the customer. As a result, our findings suggest that a complaining customer is more likely to feel worse than to feel the same or better, if the airline hands off the customer to some other organizational entity rather than resolving the complaint on social media, thereby providing support for $\mathrm{H} 3$.

\subsection{Robustness Test: Controlling for the Personality of the Customer}

Although we have controlled for conversation and customer specific characteristics, one may be concerned about the likely omitted variable bias due to personality traits that might influence a customer's emotional status at the end of the conversation with the airline on social media. If the differences between customer personalities lead to differences in the emotional status of the customer at the end of the conversation with the airline, our estimation will be biased. To alleviate this concern, we augment our benchmark model with the Big Five personality traits (i.e. Openness, Conscientiousness, Extraversion, Agreeableness, Neuroticism), which have long been shown to affect various human behaviors [21]. Traditionally, these personality traits have been measured with the use of personality questionnaires. However, on social media, most people are not willing to spend the extra effort in responding to such questionnaires, making the measurement of personality difficult [22]. Therefore, deriving personality from people's writings on social media has become an attractive option for the researchers.

Several previous studies successfully attempted to derive personality traits from people's writings based on the already established relationship between word use and personality [23][24]. The abundance of publicly available information on social media has enabled the researchers to explore the feasibility of deriving the personality traits from social media text. Yarkoni and colleagues [25] examined web blogs and showed that people's word use reliably correlate with their personality. Several recent research studied people's writings on Twitter and/or Facebook to predict their personality [40][27][28][29]. Almost all these previous studies used lexicons such as Linguistic Inquiry and Word Count (LIWC) dictionary to extract word features from text. Although the findings on the accuracy of such lexicon-based personality predictions are mixed, the predicted personality values from some studies have shown moderate correlations with the personality measurements from the questionnaires [27].

To understand the effect of the derived personality traits, we derived all the five traits for each customer in a lexicon-based approach, using the customer's past tweets as input to the LIWC dictionary [30] trait is computed using the number of words that correspond to the words in a LIWC word category that is known to correlate with the trait. Given a vector containing the correlation coefficients, and a vector containing word counts of corresponding word categories, the trait is computed as the dot product of the two vectors, i.e. a linear combination of the word counts weighted by the correlation coefficients [36]. For this study, we adopt the significant correlations from Yarkoni et. al. [25], as the correlations are based on a substantially larger corpus in comparison to other similar work [40][27][29], and also because their effectiveness of deriving personality traits has been independently validated and used by other researchers [36][28]. 
We introduce variables to our benchmark model representing the Big Five personality traits of the customer in each conversation which have been computed using LIWC 2001 and LIWC 2015 dictionaries separately. We re-estimate the ordered-logit specification of the benchmark model and the results are presented in column (3) and column (4) of Table 2. The results are qualitatively similar to our major findings of the benchmark model.

\section{Discussion and Conclusion}

Working with a unique dataset of customer conversations on Twitter to a major airline, we investigate the relationship between a complaining customer's social media influence, type of the complaint, and the occurrence of handoffs during the encounter, on the emotional satisfaction of that customer at the end of the conversation with the brand on social media. In order to learn customers' perception of how they felt at the end of the interaction with the airline, we conducted our Closed Loop Social Surveillance (CLSS) survey methodology among a random sample of 1,500 customers who engaged in a complaint-based conversation with the airline on Twitter. We have some notable findings.

First, we find that the complaining customers with a higher number of followers are more likely to feel better at the end of the conversation with the brand. This may be because of the likely existence of a social media influence based preferential customer service, or, simply because socially popular customers are happier and emotionally more stable individuals in general, than the less-popular ones. Regardless of its cause, this finding reveals the brands an important segment of customers who can be easily pleased even in tense situations such as complaint handling. The brands may want to revisit and revise their social media complaint management strategies to handle these customers accordingly.

Surprisingly, $53 \%$ of the customers reported that they felt worse at the end of the conversation with the brand on social media, which clearly undermines the investment a brand would make in the intention of providing high-quality social media customer service. Furthermore, just $10.60 \%$ of the customers believed that their problem was resolved on social media while 39\% of the customers had been referred to other departments instead. We find that customers who were referred to other departments are more likely to feel worse at the end. It appears that customers tend to perceive a service handoff as a way of "passing the buck", rather than reflecting the social media team's inability to resolve their complaints. Moreover, we find that the customers who complained about unprofessional employees or dedicated customer service issues were more likely to feel worse at the end, than those who complained about outcome or operations related issues.

Our findings have important implications for companies that strive to harness the power of social media to provide customer service. First is the pressing need to empower the social media team. The reasons for the previously reported very low problem resolution rate and the high handoff rate may be due to lack of technology infrastructure, training opportunities, and budget available to social media teams. Therefore, a careful social media investment strategy should be defined at the corporate level, enabling seamless integration between the social media team and the dedicated customer service of the brand. Furthermore, social media teams should be given continuous and mandatory training opportunities in learning to provide high-quality complaint resolutions faster.

Another implication for practice would be to pay more attention to service process related complaints on social media, as these are less likely to make the customer feel better in the end. Our findings also suggest that most customers would understand that things may sometimes go wrong in airline operations, but when it comes to issues involving employee attitude, they find it harder to forgive. Therefore, in addition to reassuring the customer that necessary organizational actions will be taken against the reported unprofessionalism, it may also be worthwhile to cheer the customer with some means of a relevant compensation.

\section{References}

[1] Nikbin, D., Armesh, H., Heydari, A., and Jalalkamali, M. 2011. "The Effects of Perceived Justice in Service Recovery on Firm Reputation and Repurchase Intention in Airline Industry," African Journal of Business Management (5:23), pp. 9814-9822.

[2] Del Río-Lanza, A. B., Vázquez-Casielles, R., and DíazMartín, A. M. 2009. "Satisfaction with Service Recovery: Perceived Justice and Emotional Responses," Journal of Business Research (62:8), pp. 775-781.

[3] Smith, A. K., Bolton, R. N., and Wagner, J. 1999. “A Model of Customer Satisfaction with Service Encounters Involving Failure and Recovery," Journal of Marketing Research (36: August), pp. 356-372

[4] Fornell, C. 1976. "Consumer Input for Marketing Decisions: A Study of Corporate Departments for Consumer Affairs," New York: Praeger Publishers.

[5] Tax, S. S., Brown, S. W., and Chandrashekaran, M. 1998. "Customer Evaluations of Service Complaint Experiences: Implications for Relationship Marketing," Journal of Marketing (62: April), pp. 60-76.

[6] Levesque, T. J. and McDougall, G. H. 1996. "Customer Dissatisfaction: The Relationship between Types of 
Problems and Customer Response," Canadian Journal of Administrative Sciences (13:3), pp.264-276.

[7] Estelami, H. 2000. "Competitive and Procedural Determinants of Delight and Disappointment in Consumer Complaint Outcomes," Journal of Service Research (2:3), pp.285-300.

[8] Davidow, M. 2000. "The Bottom Line Impact of Organizational Responses to Customer Complaints," Journal of Hospitality \& Tourism Research (24:4), pp. 473-490.

[9] Strauss, J., and Hill, D. J. 2001. "Consumer Complaints by E-mail: An Exploratory Investigation of Corporate Responses and Customer Reactions," Journal of Interactive Marketing" (15:1), pp.63-73.

[10] Oliver, R. (1997), Satisfaction: A Behavioral Perspective on the Consumer, New York: McGrawHill.

[11] Smith, A. K., and Bolton, R. N. 2002. "The Effect of Customers' Emotional Responses to Service Failures on Their Recovery Effort Evaluations and Satisfaction Judgments," Journal of the Academy of Marketing Science (30:1), pp.5-23.

[12] Berry, L. L, and Parasuraman A., 1991. Marketing Services: Competing Through Quality. New York: Free Press.

[13] Zeithaml, V. A., Berry, L. L., and Parasuraman, A. 1993. "The Nature and Determinants of Customer Expectations of Service," Journal of the Academy of Marketing Science (21:1), pp.1-12.

[14] Allon, G. and Zhang, D. J. October 12, 2015. "Managing Service Systems in the Presence of Social Networks," Available at SSRN: http://ssrn.com/abstract=267313

[15] Bonchi, F., Castillo, C., Gionis, A., and Jaimes, A. 2011. "Social Network Analysis and Mining for Business Applications," ACM Transactions on Intelligent Systems and Technology (TIST) (2:3), Article 22.

[16] Bitner, M. J., Booms, B. H., and Tetreault, M. S. 1990. "The Service Encounter: Diagnosing Favorable and Unfavorable Incidents," The Journal of Marketing (54:1), pp. 71-84.

[17] Gensler, S., Völckner, F., Liu-Thompkins, Y., and Wiertz, C. 2013. "Managing Brands in the Social Media Environment," Journal of Interactive Marketing (27:4), pp. 242-256.

[18] Joinson, A. N. 2008. "Looking at, Looking up or Keeping up with People?: Motives and Use of Facebook," in Proceeding of the Twenty-Sixth Annual SIGCHI Conference on Human Factors in Computing Systems, ACM, pp. 1027-1036.

[19] Marwick, A. 2012. "The Public Domain: Surveillance in Everyday Life," Surveillance \& Society (9:4), pp. 378393.

[20] Tokunaga, R. S. 2011. "Social Networking Site or Social Surveillance Site? Understanding the Use of Interpersonal Electronic Surveillance in Romantic Relationships," Computers in Human Behavior (27: 2), pp. 705-713.

[21] Goldberg, L. R. 1993. The Structure of Phenotypic Personality Traits. American Psychologist (48:1).

[22] Chen, J., Haber, E., Kang, R., Hsieh, G., and Mahmud, J. 2015, April. "Making Use of Derived Personality:
The Case of Social Media Ad Targeting," In Ninth International AAAI Conference on Web and Social Media.

[23] Fast, L.A., and Funder, D.C. 2008. "Personality as Manifest in Word Use: Correlations with Self-Report, Acquaintance Report, and Behavior," Journal of Personality and Social Psychology (94:2), p. 334.

[24] Hirsh, J.B., and Peterson, J.B. 2009. "Personality and Language Use in Self-Narratives," Journal of Research in Personality (43:3), pp. 524-527.

[25] Yarkoni, T. 2010. "Personality in 100,000 Words: A Large-Scale Analysis of Personality and Word Use among Bloggers," Journal of Research in Personality (44:3), pp. 363-373.

[26] Golbeck, J., Robles, C., Edmondson, M., and Turner, K. (2011, October). "Predicting Personality from Twitter," In Privacy, Security, Risk and Trust (PASSAT) and 2011 IEEE Third International Conference on Social Computing (SocialCom), 2011 IEEE Third International Conference on (pp. 149-156). IEEE.

[27] Golbeck, J., Robles, C., and Turner, K. 2011, May. "Predicting Personality with Social Media," In CHI'11 Extended Abstracts on Human Factors in Computing Systems, pp. 253-262). ACM.

[28] Gou, L., Zhou, M. X., and Yang, H. 2014, April. "Know Me and Share Me: Understanding Automatically Discovered Personality Traits from Social Media and User Sharing Preferences," In Proceedings of the SIGCHI Conference on Human Factors in Computing Systems, pp. 955-964. ACM.

[29] Sumner, C., Byers, A., Boochever, R., and Park, G. J. 2012, December. "Predicting Dark Triad Personality Traits from Twitter Usage and a Linguistic Analysis of Tweets," In Machine Learning and Applications (ICMLA), 2012 11th International Conference on (Vol. 2, pp. 386-393). IEEE.

[30] Pennebaker, J. W., Boyd, R. L., Jordan, K., and Blackburn, K. 2015. "The Development and Psychometric Properties of LIWC2015".

[31] Seiders, K., and Berry, L. L. 1998. "Service Fairness: What it is and Why it Matters," The Academy of Management Executive (12:2), pp.8-20.

[32] Homans, G. C. 1961. "Social Behavior: Its Elementary Forms,". New York: Harcourt, Brace \& World.

[33] Walster, E., Berscheid, E., and Walster, G.W. 1973, "New Directions in Equity Research," Journal of Personality and Social Psychology (25:2), pp.151-76.

[34] Hart, C. W., Heskett J. L., and Sasser Jr., W.E. 1990, "The Profitable Art of Service Recovery," Harvard Business Review (68 :July/August), pp.148-56

[35] Boshoff, C. 1999. "RECOVSAT An Instrument to Measure Satisfaction with Transaction-Specific Service Recovery," Journal of Service Research (1:3), pp.236249.

[36] Boshoff, C. and Leong J. 1998, "Empowerment, Attribution and Apologising as Dimensions of Service Recovery: An Experimental Study," International Journal of Service Industry Management (9:1), pp.2447. 